\title{
The Caudal Migratory Stream: A Novel Migratory Stream of Interneurons Derived from the Caudal Ganglionic Eminence in the Developing Mouse Forebrain
}

\author{
Masato Yozu, ${ }^{1}$ Hidenori Tabata, ${ }^{1}$ and Kazunori Nakajima ${ }^{1,2}$ \\ ${ }^{1}$ Department of Anatomy, Keio University School of Medicine, Tokyo 160-8582, Japan, and 2Department of Molecular Neurobiology, Institute of DNA \\ Medicine, Jikei University School of Medicine, Tokyo 105-8461, Japan
}

\begin{abstract}
The migratory paths of interneurons derived from the ganglionic eminence (GE), and particularly its caudal portion (CGE), remain essentially unknown. To clarify the three-dimensional migration profile of interneurons derived from each part of the GE, we developed a technique involving focal electroporation into a small, defined portion of the telencephalic hemisphere. While the medial GE cells migrated laterally and spread widely throughout the cortex, the majority of the CGE cells migrated caudally toward the caudal-most end of the telencephalon. Time-lapse imaging and an in vivo immunohistochemical study confirmed the existence of a migratory stream depicted by a population of CGE cells directed caudally that eventually reached the hippocampus. Transplantation experiments suggested that the caudal direction of migration of the CGE cells was intrinsically determined as early as embryonic day 13.5 . The caudal migratory stream is a novel migratory path for a population of CGE-derived interneurons passing from the subpallium to the hippocampus.
\end{abstract}

Key words: GABAergic interneurons; cortical development; neuronal migration; medial ganglionic eminence; caudal ganglionic eminence; electroporation

\section{Introduction}

The cerebral cortex contains two major classes of neurons, the glutamatergic projection neurons and the GABAergic interneurons. In the developing cerebral cortex, most interneurons are known to derive from the subpallial telencephalon and migrate tangentially into the pallium in mice (Parnavelas, 2000; Corbin et al., 2001; Marin and Rubenstein, 2001, 2003; Nadarajah and Parnavelas, 2002). The subpallium provides interneurons to the neocortex, hippocampus, and olfactory bulb through tangential migration (Anderson et al., 1997b; Lavdas et al., 1999; Sussel et al., 1999; Corbin et al., 2000; Pleasure et al., 2000; Wichterle et al., 2001). The subpallium can be divided into three major proliferative zones [the medial ganglionic eminence (MGE), the lateral ganglionic eminence (LGE), and the caudal ganglionic eminence (CGE)] based on anatomical and gene expression features (Casarosa et al., 1999; Sussel et al., 1999; Corbin et al., 2000; Puelles et al., 2000; Nery et al., 2002). Although the MGE is known to be the main source of tangentially migrating interneurons (Lavdas et al., 1999; Sussel et al., 1999; Pleasure et al., 2000), the CGE and LGE

Received May 23, 2005; revised June 24, 2005; accepted June 29, 2005.

This work was supported by the Japan Science and Technology Corporation, the Ministry of Education, Culture, Sports, Science, and Technology of Japan, the Japan Society for the Promotion of Science, a grant-in-aid from the 21st Century Center of Excellence Program entitled "Understanding and Control of Life's Function via Systems Biology," a Keio University Special Grant-in-Aid for Innovative Collaborative Research Projects, the Novartis Foundation, the Casio Science Promotion Foundation, and the Japan Brain Foundation. We declare that we have no competing financial interests.

Correspondence should be addressed to Dr. Kazunori Nakajima, Department of Anatomy, Keio University School of Medicine, 35 Shinanomachi, Shinjuku-ku, Tokyo 160-8582, Japan. E-mail: kazunori@sc.itc.keio.ac.jp.

DOI:10.1523/JNEUROSCI.2072-05.2005

Copyright $\odot 2005$ Society for Neuroscience $\quad$ 0270-6474/05/257268-10\$15.00/0 also give rise to interneurons destined to the neocortex and hippocampus or the olfactory bulb (Wichterle et al., 1999, 2001; Corbin et al., 2000; Anderson et al., 2001; Nery et al., 2002). Recently, research efforts have focused on revealing the mechanisms that control the tangential migration from the subpallium to the developing cerebral cortex (Denaxa et al., 2001; Marin and Rubenstein, 2001; Marin et al., 2001; Powell et al., 2001; Polleux et al., 2002; Wichterle et al., 2003; Alifragis et al., 2004; Flames et al., 2004). Because all of these reports have focused on interneurons derived from the MGE or LGE, little is known about the migratory profile of CGE-derived interneurons.

In an attempt to analyze the characteristics of the interneuron migration, particularly CGE-derived interneuron migration, we developed a technique to transfect and label a population of interneurons derived from a small, defined portion of the telencephalic hemisphere. Using this technique, in combination with whole-mount telencephalic hemisphere cultures, we were able to visualize the migration of interneurons derived from specific parts of the ganglionic eminence (GE). While the MGE cells migrated laterally and spread widely throughout the cortex, the majority of CGE cells migrated caudally toward the caudal-most end of the telencephalon. Time-lapse imaging of slice cultures and an in vivo immunohistochemical study also clearly revealed a caudally directed migratory stream of a population of CGE cells that eventually reached the hippocampus. Transplantation experiments suggested that the mechanisms controlling the direction of the migration of the CGE and MGE cells from the subpallium to the developing cerebral cortex were distinct from each other and that these mechanisms were intrinsically determined in the mi- 

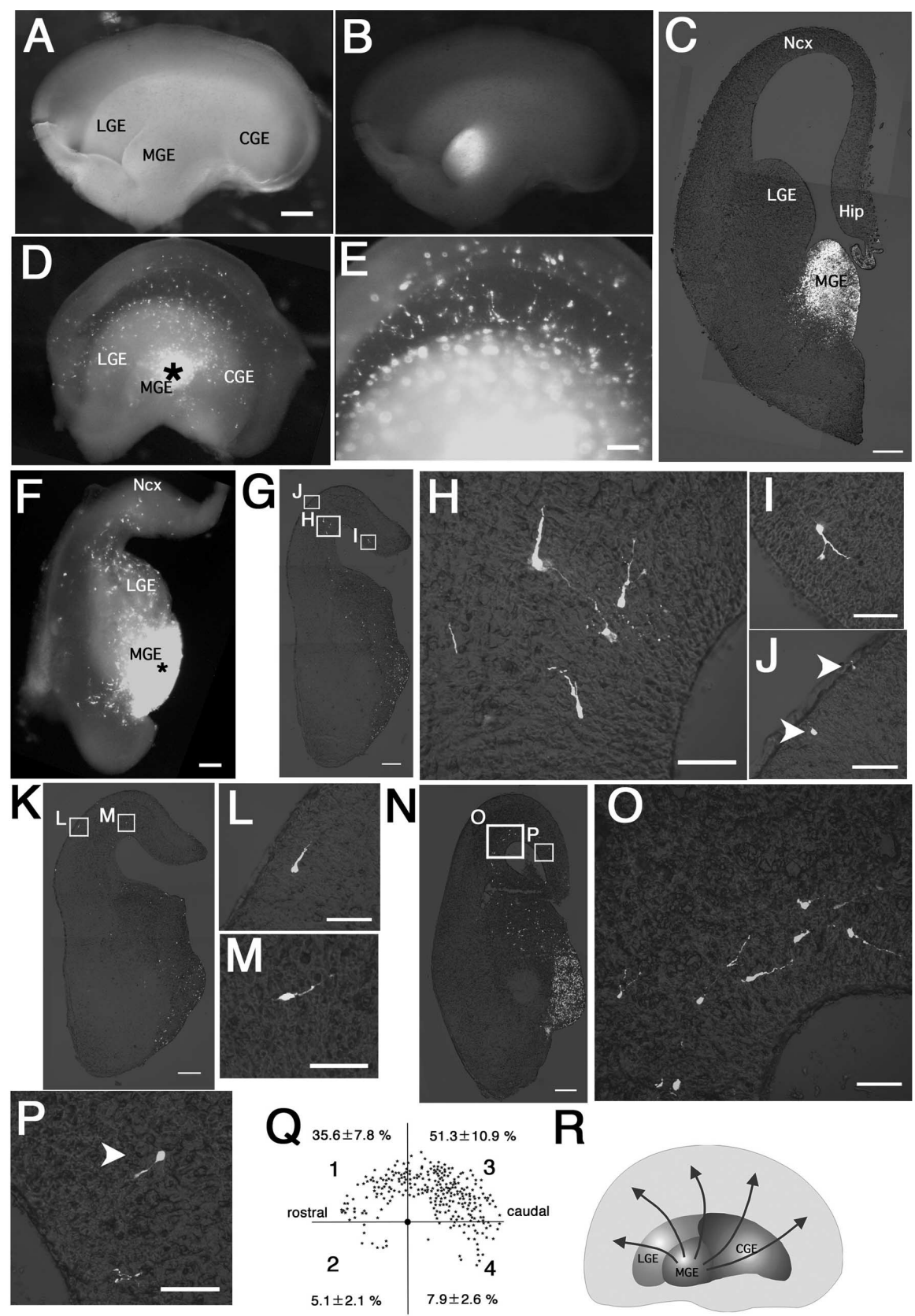

$\mathbf{R}$

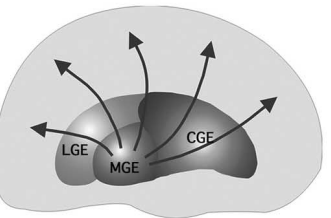

Figure 1. MGE cells migrate laterally and spread widely throughout the cerebral cortex. $\boldsymbol{A}-\boldsymbol{C}$, Focal electroporation of an FITC-labeled oligonucleotide into E13.5 MGE. Bright-field $(\boldsymbol{A})$ and fluorescent $(\boldsymbol{B})$ images of the whole-mount hemisphere and its coronal section $(\boldsymbol{C})$ indicate that the MGE was indeed specifically labeled. D-P, MGE was electroporated with DsRedEx/CAG at E13.5 and cultured for 40 h. D, $\boldsymbol{E}$, Medial view of the hemisphere. MGE cells migrated laterally and spread widely throughout the cortex. $\boldsymbol{E}$, Higher magnification of $\boldsymbol{D}$. The asterisks in $\boldsymbol{D}$ and $\boldsymbol{F}$ show the point of transfection. $\boldsymbol{F}$, Thick coronal section (300 $\mu \mathrm{m}$ thick) of the hemisphere. MGE cells migrated tangentially from the MGE to the cortex. G-P, Thin coronal sections (14 $\mu$ m thick) of the hemisphere. $\boldsymbol{H}-\boldsymbol{J}, \boldsymbol{L}, \boldsymbol{M}, \mathbf{0}, \boldsymbol{P}$, Highermagnification of the boxed areas in $\boldsymbol{G}, \boldsymbol{K}$, and $\boldsymbol{N}$, respectively. Some MGE cells showed tangentially migrating morphology from the lateral cortex to the medial cortex ( $\mathbf{G}-\mathbf{I}, \boldsymbol{K}-\mathbf{0})$. MGE cells also migrated in the superficial layer (J, arrowheads). Some cells showed ventricle-directed migration in the cortex ( $\boldsymbol{P}$, arrowhead). $\mathbf{Q}$, Distribution of the MGE-derived fluorescent cells in the GE. Each dot represents one cell. The percentage of MGE cells in each sector was counted [average \pm SD (\%)]. The black dot in the center represents the site of electroporation. Note that only $7.9 \pm 2.6 \%$ (SD) of the MGE cells migrated into sector $4 . \boldsymbol{R}$, Schema of the migratory route of MGE cells. Hip, Hippocampus; Ncx, neocortex. Scale bars: $\boldsymbol{A}, \boldsymbol{B}, \boldsymbol{D}, 400 \mu \mathrm{m} ; \boldsymbol{C}, \boldsymbol{F}, \mathbf{G}, \boldsymbol{K}, \boldsymbol{N}, 200 \mu \mathrm{m} ; \boldsymbol{E}, 220 \mu \mathrm{m} ; \boldsymbol{H}-\mathbf{J}, \mathbf{L}, \boldsymbol{M}, \mathbf{O}, \boldsymbol{P}, 50 \mu \mathrm{m}$.

grating GE cells by at least embryonic day 13.5 (E13.5). Because this caudal stream of migration depicted by a population of CGE cells differs from the well known pathway of interneuron migration from the MGE/LGE, we named this novel migratory stream the caudal migratory stream (CMS).

\section{Materials and Methods}

Animals. All animal experiments were performed according to the Guidelines for the Care and Use of Laboratory Animals of Keio University School of Medicine. Pregnant Institute of Cancer Research (ICR) mice were purchased from Japan SLC (Shizuoka, Japan). The day on which a vaginal plug was detected was designated as E0.

Definition of CGE. The CGE was defined as the region posterior to the fusion of the MGE and LGE into a single structure, as defined in a previous report (Nery et al., 2002).

Focal electroporation into the telencephalic hemisphere. Telencephalic hemispheres from E13.5 ICR mouse embryos were dissected out in PBS. The dissections were made between the telencephalon and diencephalon. Red fluorescent protein (DsRed-Express; Clontech, Palo Alto, CA) expression vector with a modified chicken $\beta$-actin promoter with a cytomegalovirus-immediate-early enhancer (CAG) promoter (Niwa et al., 1991) was dissolved in HEPES-buffered saline buffer $(2 \%$ HEPES, $0.8 \% \mathrm{NaCl}, 5 \mathrm{~mm} \mathrm{KCl}, 0.7 \mathrm{~mm}$ $\mathrm{Na}_{2} \mathrm{HPO}_{4} 12 \mathrm{H}_{2} \mathrm{O}$, and $0.1 \%$ glucose) at a concentration of $4 \mu \mathrm{g} / \mu \mathrm{l}$, and Fast Green solution (0.1\%; Sigma, St. Louis, MO) was added to the plasmid solution at a ratio of $1: 10$ to monitor the injection (Tabata and Nakajima, 2001). Approximately $0.1 \mu \mathrm{l}$ of the plasmid solution was injected into the MGE or CGE using a glass micropipette in PBS. The telencephalic hemispheres were placed between a platinum plate electrode and a tungsten needle electrode (see supplemental Fig. 1, available at www. jneurosci.org as supplemental material). Electronic pulses (100 V, $5 \mathrm{~ms}$ ) were charged two times at intervals of $5 \mathrm{~ms}$ using an electroporater (CUY21E; Nepa Gene, Chiba, Japan).

Fluorescein isothiocyanate-labeled oligonucleotide. A fluorescein isothiocyanate (FITC)labeled oligonucleotide (5'-FITC-TACGTACGTACGTA-3'), which had been used to show the site of electroporation as a marker in the previous experiments (K. Ikenaka, personal communication), was dissolved in $10 \mathrm{~mm}$ Tris$\mathrm{HCl}, \mathrm{pH} 7.5$, at a concentration of $20 \mu \mathrm{g} / \mu \mathrm{l}$, pretreated at $90^{\circ} \mathrm{C}$ for $3 \mathrm{~min}$, and cooled down gradually before the electroporation.

Whole telencephalic hemisphere cultures. Electroporated E13.5 telencephalic hemispheres were cultured in $2 \mathrm{ml}$ of DMEM nutrient mixture/Ham's F-12 (Sigma) containing N-2 supplement (Invitrogen, Carlsbad, CA) for $40 \mathrm{~h}$ in rotating glass bottles with continuous gas flow $\left(95 \% \mathrm{O}_{2}\right.$ and $5 \% \mathrm{CO}_{2}$ at $37^{\circ} \mathrm{C}$ ) (Nagata and Terashima, 1994; T. Honda, H. Tabata, and K. Nakajima, unpublished observations). Images of the whole-mount telencephalic hemispheres were acquired using a CCD camera (C5810; Hamamatsu, Shizuoka, Japan) connected with a fluorescence dissecting microscope (MZFLIII; Leica, Wetzlar, Germany).

Telencephalic hemisphere transplantation. Small fragments of the ventricular zone or subventricular zone from the electroporated E13.5 MGE or CGE were dissected out and transplanted into a small hole made in the MGE or CGE of the recipient E13.5 telencephalic hemispheres. The transplanted hemispheres were processed for the telencephalic hemisphere cultures as described above. 
Time-lapse imaging. Time-lapse analyses were performed as described previously ( $\mathrm{Ta}$ bata and Nakajima, 2003). Briefly, after the electroporated E13.5 telencephalic hemispheres had been cultured for $40 \mathrm{~h}$, coronal or horizontal brain slices (200 $\mu \mathrm{m}$ thick) were made, placed on a Millicell-CM (pore size, 0.4 $\mu \mathrm{m}$; Millipore, Bedford, MA), mounted in collagen gel, and cultured in Neurobasal medium containing B27 (Invitrogen, San Diego, CA). The dishes were then mounted in a $\mathrm{CO}_{2}$ incubator chamber $\left(5 \% \mathrm{CO}_{2}\right.$ at $\left.37^{\circ} \mathrm{C}\right)$ fitted onto a confocal microscope (FV300; Olympus Optical, Tokyo, Japan). Approximately 10-20 optical Z sections (Z-steps; $5 \mu \mathrm{m}$ ) were obtained automatically every $15 \mathrm{~min}$, and all of the focal planes (50-100 $\mu \mathrm{m}$ thick) were merged to visualize the shape of the entire cell.

Injection of bromodeoxyuridine. Pregnant ICR mice were given injections of $50 \mu \mathrm{g}$ of bromodeoxyuridine (BrdU; Sigma) per gram of body weight, as described previously (Yozu et al., 2004).

Immunohistochemistry. The immunohistochemical analyses were performed as described previously (Tabata and Nakajima, 2001). Briefly, deeply anesthetized animals were fixed by perfusion with $4 \%$ paraformaldehyde (PFA) in $0.1 \mathrm{~m}$ sodium phosphate buffer, $\mathrm{pH}$ 7.4. The brains were then dissected out and postfixed in $4 \%$ PFA for $12-16 \mathrm{~h}$ at $4^{\circ} \mathrm{C}$. For the immunostaining, horizontal sections (14 $\mu \mathrm{m}$ thick) were made using a cryostat (CM1900; Leica) and incubated overnight with the following primary antibodies: anti-calbindin (rabbit polyclonal; 1:1000; Swant, Bellinzona, Switzerland) and anti-calretinin (rabbit polyclonal; 1:1000; Chemicon, Temecula, CA). After washing, the sections were incubated with FITC-conjugated anti-rabbit IgG (1:100; Cappel, Aurora, OH) and propidium iodide (PI) $(1 \mu \mathrm{g} / \mathrm{ml}$; Molecular Probes, Eugene, OR) at room temperature for $1 \mathrm{~h}$. For the BrdU staining, the sections were treated with $2 \mathrm{~N} \mathrm{HCl}$ at $37^{\circ} \mathrm{C}$ for $30 \mathrm{~min}$, rinsed in PBS, and processed for immunostaining using anti-BrdU (mouse monoclonal; 1:50; Becton Dickinson, San Jose, CA) as the primary antibody and tetramethylrhodamine isothiocyanate-conjugated anti-mouse IgG (1: 200; Jackson ImmunoResearch, Baltimore Pike, PA) as the secondary antibody. Images were acquired using a confocal microscope (FV300; Olympus). For the immunohistochemical analysis of the cultured telencephalic hemisphere, hemispheres were fixed in $4 \%$ PFA for $12-16 \mathrm{~h}$ at $4^{\circ} \mathrm{C}$ and processed for immunohistochemical analysis as described above.

Statistical analysis. Significant differences in this study were determined using a two-tailed Student's $t$ test.

\section{Results}

MGE cells migrate laterally and spread widely throughout the cerebral cortex

To clarify the three-dimensional migratory profile of interneurons originating from each part of the GE, we initially dissected out the E13.5 mouse telencephalic hemisphere and performed focal electroporation into the MGE. FITC-labeled oligonucleotide was used as a marker to confirm that the site of gene transfer
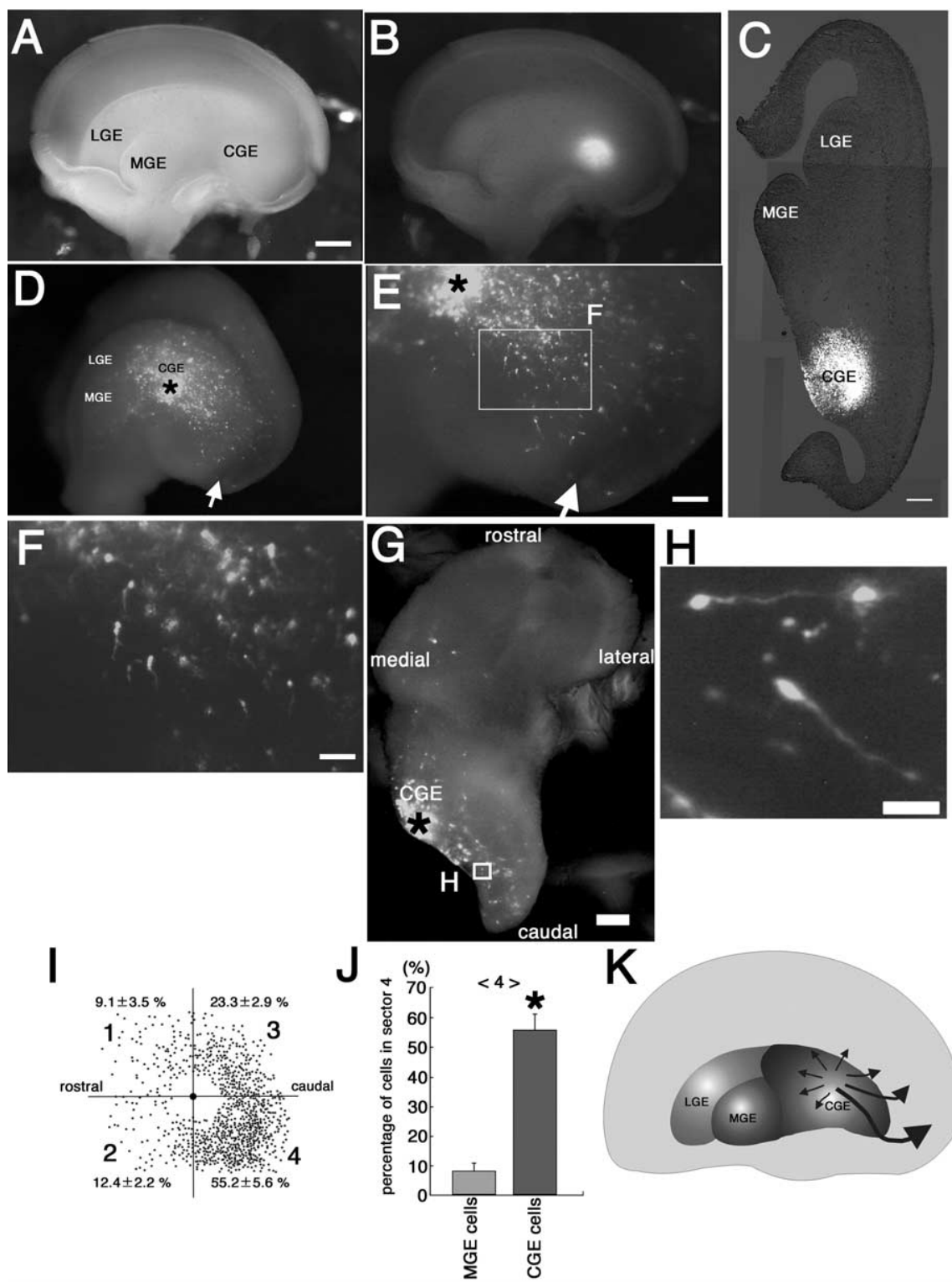

Figure 2. A population of CGE-derived cells migrate caudally toward the caudal-most end of the telencephalon. $\boldsymbol{A}-\boldsymbol{C}, A n$ FITC-labeled oligonucleotide was electroporated into the CGE of E13.5 telencephalichemispheres. Bright-field $(\boldsymbol{A})$ and fluorescent $(\boldsymbol{B})$ images of the whole-mount hemisphere and its horizontal section $(\boldsymbol{C})$ are shown. $\boldsymbol{D}-\boldsymbol{H}$, Medial view $(\boldsymbol{D}-\boldsymbol{F})$ and horizontal section $(\boldsymbol{G}, \boldsymbol{H})$ of a hemisphere cultured for $40 \mathrm{~h}$ after the local electroporation of DsRedEx/CAG into the CGE on E13.5. The majority of CGE cells migrated caudally toward the caudal-most end of the telencephalon. The asterisks show the point of transfection. The arrow indicates the caudal end of the CGE. $\boldsymbol{E}$, Higher magnification of $\boldsymbol{D}$. $\boldsymbol{F}, \boldsymbol{H}$, Higher magnification of the boxed areas in $\boldsymbol{E}$ and $\boldsymbol{G}$, respectively. $I$, Distribution of the CGE-derived fluorescent cells in the GE in the medial view. Labeled cells were counted at different focal planes. Note that $55.2 \pm 5.6 \%$ (SD) of the CGE-derived fluorescent cells migrated into sector 4.J, Quantification of the percentages of MGE-derived (Fig. 1Q) or CGE-derived (I) cells in sector 4. In sector 4, the percentage of CGE-derived cells was significantly larger than that of the MGE-derived cells $\left({ }^{*} p<0.01\right.$; data from 3 independent experiments). $\boldsymbol{K}$, Schema of the migratory routes of the CGE cells. Scale bars: $\boldsymbol{A}, \boldsymbol{B}, \boldsymbol{D}, 400 \mu \mathrm{m} ; \boldsymbol{C}, \boldsymbol{E}, \boldsymbol{G}, 200 \mu \mathrm{m} ; \boldsymbol{F}, 60 \mu \mathrm{m} ; \boldsymbol{H}, 30 \mu \mathrm{m}$. 

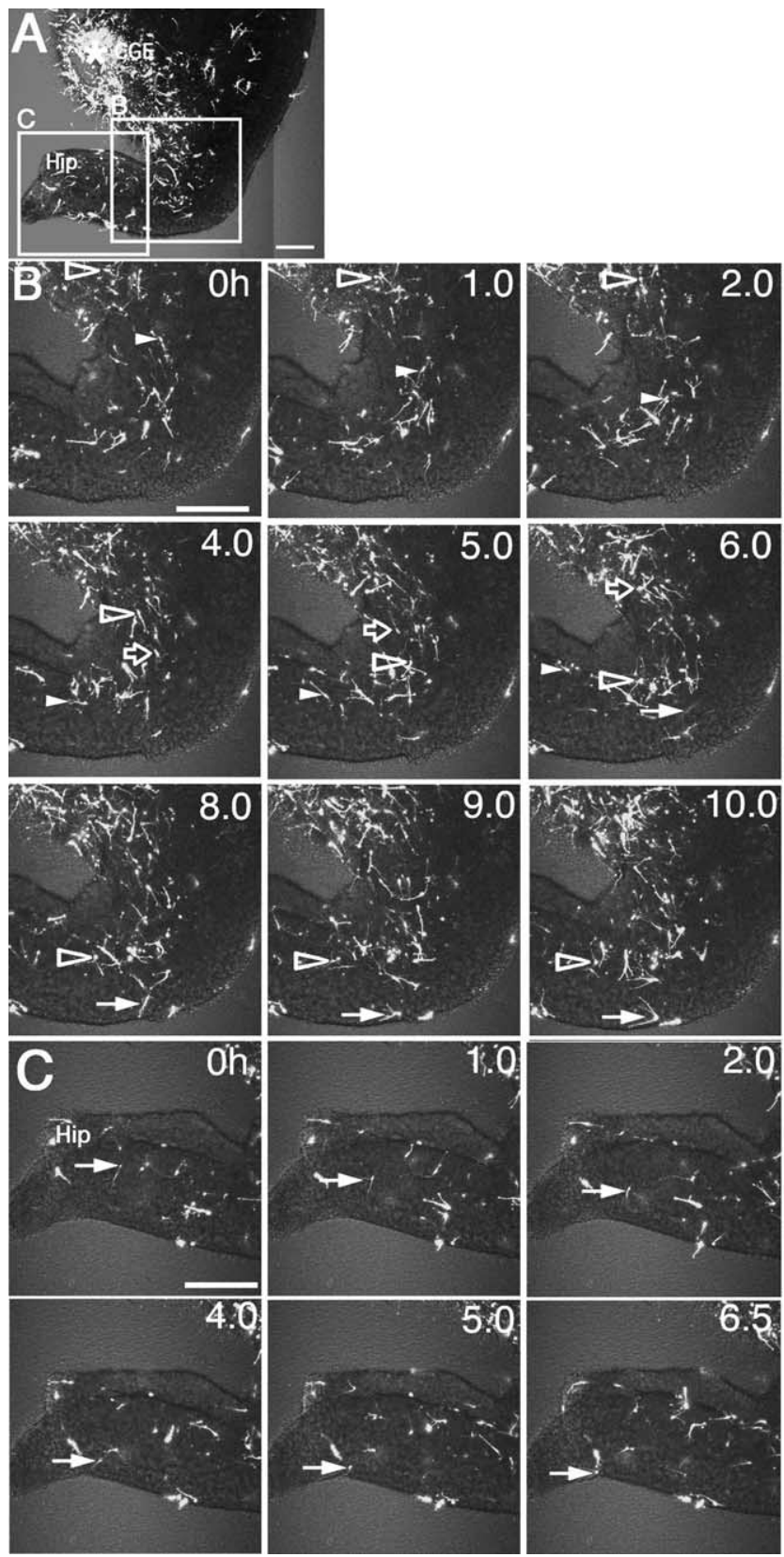

Figure 3. Time-lapse imaging of the caudally migrating cells derived from the CGE. $\boldsymbol{A}-\boldsymbol{C}$, Horizontal slices were prepared at $40 \mathrm{~h}$ in vitro after local electroporation into the CGE of E13.5 telencephalic hemispheres. The asterisk in $\boldsymbol{A}$ shows the place of electroporation. $\boldsymbol{B}, \boldsymbol{C}$, Time-lapse images of caudally migrating cells from the boxed area in $\boldsymbol{A}$. A significant number of the CGE-derived cells contributed to the depiction of a clear migratory stream toward the hippocampus. The solid arrowhead $(0-7.0$ $\mathrm{h}$ in $\boldsymbol{B})$ and the open arrowhead $(0-10.0 \mathrm{~h}$ in $\boldsymbol{B})$ point to two caudally migrating cells in the migratory stream. The solid arrows point to a caudally migrating cell that changed direction and moved toward the $\mathrm{MZ}(6.0-10.0 \mathrm{~h}$ in $\boldsymbol{B}, 0-6.5 \mathrm{~h}$ in $\mathrm{C}$ ). The open arrow points to a CGE-derived cell moving in the opposite direction to the stream $(4.0-6.0 \mathrm{~h}$ in $\boldsymbol{B})$. $\boldsymbol{D}$, Schema of the migratory paths of the CGE-derived cells in the horizontal slice. Scale bars: $\boldsymbol{A}-\mathbf{C}, 200 \mu \mathrm{m}$. Hip, Hippocampus.

dal direction, only $7.9 \pm 2.6 \%$ (SD) of the MGE-derived fluorescent cells migrated into sector 4 . The coronal sections (300 $\mu \mathrm{m}$ thick) of the cultured telencephalic hemispheres showed robust tangentially migrating cells from the MGE to the cortex (Fig. $1 F$ ). To examine the brain condition and the ability of the MGE cells to migrate after $40 \mathrm{~h}$ in the entire telencephalic hemisphere cultures, we performed time-lapse imaging of the MGE cells in slice cultures (supplemental Fig. 2 and supplemental movie 1, available at www.jneurosci.org as supplemental material). Coronal slices of cultured telencephalic hemispheres were prepared at $40 \mathrm{~h}$
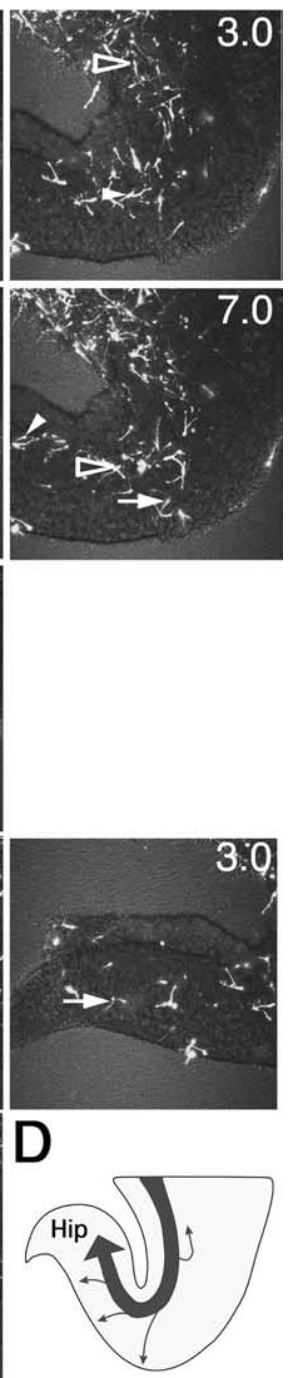

in vitro after local electroporation into the MGE at E13.5. A number of MGE cells migrated tangentially from the MGE to the cortex. This migratory behavior of the MGE cells was consistent with the numerous previous observations using the well established slice culture system (de Carlos et al., 1996; Anderson et al., 1997b; Tamamaki et al., 1997; Lavdas et al., 1999; Wichterle et al., 1999; Polleux et al., 2002; Tanaka et al., 2003). These results imply that the brain condition was fairly well preserved at $40 \mathrm{~h}$ in the entire telencephalic hemisphere cultures. To observe the morphology of the migrating cells in the cortices, coronal thin sections $(14 \mu \mathrm{m}$ thick) of the cultured telencephalic hemispheres were prepared (Fig. 1G-P). The sections showed tangentially oriented morphology of the migrating cells from the lateral cortex to the medial cortex (Fig. $1 G-I, K-O)$. Some MGE cells also migrated in the superficial layer (Fig. $1 \mathrm{~J}$, arrowheads). The morphology of some of the cells in the cortex was characteristic of ventricle-directed migration, as reported previously (Nadarajah et al., 2002) (Fig. $1 P$, arrowhead).

\section{A population of CGE-derived cells migrate caudally toward the caudal- most end of the telencephalon}

To visualize the migration of the CGEderived interneurons specifically, we next performed focal electroporation into the CGE of telencephalic hemispheres on E13.5. An FITC-labeled oligonucleotide clearly showed that the electroporation was indeed specifically performed into the CGE (Fig. 2A-C). After electroporating the DsRedEx/CAG into the CGE, the telencephalic hemispheres were cultured for $40 \mathrm{~h}$, and the CGE-derived cells were observed. For the quantitative analysis, the distribution of the CGE-derived fluorescent cells in the medial view was subdivided into four sectors (Fig. $2 I$ ). After $40 \mathrm{~h}$ in vitro ( $n=3$ brains), the majority of the CGE cells had migrated caudally toward the caudal-most end of the telencephalon (Fig. $2 D-F, I, K$ ). Overall, $55.2 \pm 5.6 \%$ (SD) of the CGE-derived fluorescent cells had migrated into sector 4 , which was significantly more than that of the MGE-derived cells ( $p=0.0096$ ) (Fig. 2J). The horizontal sections of the cultured telencephalic hemispheres showed the CGE cells migrated caudally (Fig. $2 G, H)$.

Time-lapse imaging of the caudally migrating cells derived from the CGE

To clarify the dynamics of the caudally migrating cells, we next performed time-lapse imaging of the CGE-derived cells in slice cultures. Horizontal slices of cultured telencephalic hemispheres 
were prepared at $40 \mathrm{~h}$ in vitro after local electroporation into the CGE at E13.5. A significant number of the CGE-derived cells exhibited a clear migratory stream from the site of electroporation in the CGE to the hippocampus (Fig. $3 A, B$, open arrowheads, solid arrowheads, $D$ ) (supplemental movie 2, available at www.jneurosci.org as supplemental material). Within the CGE, the migratory speed of the individual cells was fairly rapid, averaging $109 \pm 20.7 \mu \mathrm{m} / \mathrm{h}$ (SD) ( $n=16$ cells in three slices). The CGE-derived cells in the migratory stream changed their direction and moved toward the marginal zone (MZ) before entering the hippocampus or within the hippocampus (Fig. $3 B, C$, solid arrows, D) (supplemental movie 3, available at www. jneurosci.org as supplemental material). The CGE-derived cells that reached the MZ could be observed on the surface of the telencephalic hemispheres cultured for $40 \mathrm{~h}$ in vitro (supplemental Fig. 3, available at www.jneurosci.org as supplemental material). The migration of interneurons in the MZ derived from the GEs, including the CGE, has been well documented (Nery et al., 2002; Polleux et al., 2002; Ang et al., 2003). Some CGE-derived cells migrated in the opposite direction to the stream (Fig. $3 B$, open arrows, D) (supplemental movie 2, available at www. jneurosci.org as supplemental material). The morphological features and migratory behavior of the migrating CGE-derived cells resembled those of "branching cells"; this migratory mode is characteristic of a subset of cortical interneurons (Nadarajah et al., 2003) that are highly motile in the formation and retraction of their processes (supplemental movie 2, available at www. jneurosci.org as supplemental material).

\section{A population of the caudally migrating cells are calbindin immunoreactive}

To investigate the characteristics of the caudally migrating cells, we performed an immunohistochemical analysis of the cultured telencephalic hemispheres. After electroporating DsRedEx/CAG into E13.5 CGE, the telencephalic hemispheres were cultured for $40 \mathrm{~h}$, and horizontal sections were made. In the caudal-most end of the telencephalon, the CGE-derived cells that had not migrated toward the cortical MZ had turned toward the hippocampus (Fig. $4 A, B)$. When the horizontal sections were immunostained with anti-calbindin, a well known marker for a population of migrating embryonic GABAergic interneurons (Anderson et al., 1997b), the CGE-derived cells could be classified as strongly positive, weakly positive, or negative populations (Fig. 4C-F). When both strongly positive and weakly positive populations were regarded as calbindin positive, a quantitative analysis of the caudalmost cortices of the telencephalon revealed that $61.3 \pm 3.8 \%$ (SD) ( $n=294$ cells, four hemispheres) of the CGE-derived cells were calbindin positive. Because a recent report showed that calretinin-expressing interneurons appeared to derive mainly from the CGE (Xu et al., 2004), we also performed immunostaining with anti-calretinin, a marker of a subtype of GABAergic interneurons. However, the CGE-derived cells were calretinin negative at this embryonic stage (data not shown). This finding was likely related to the fact that most specific markers of GABAergic interneuron subsets, including calretinin, begin to be expressed during the first postnatal week (Gall et al., 1984; Takeda et al., 1989; Hill et al., 1994; de Lecea et al., 1995, 1997; Avishai-Eliner et al., 1996; Freund and Buzsaki, 1996).

\section{Existence of the CMS in vivo}

To examine whether caudally migrating cells exist in vivo, we performed an immunohistochemical analysis of mouse embryonic brains. Because caudally migrating cells were observed in
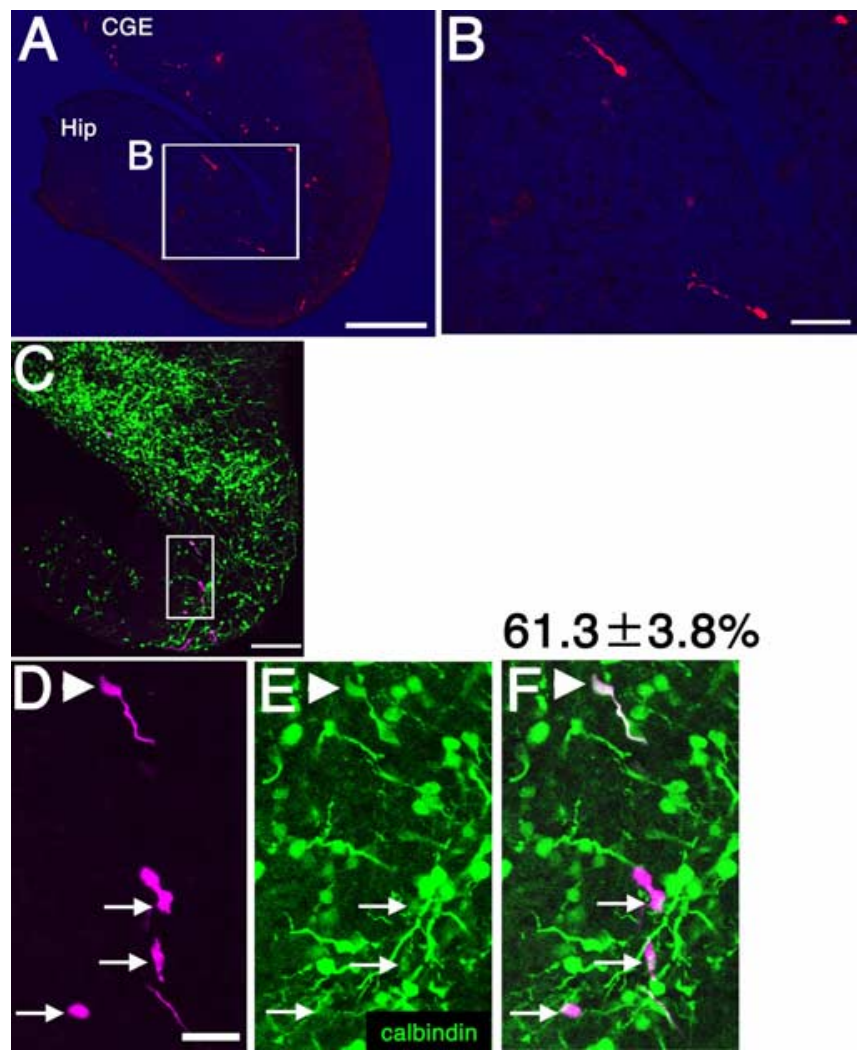

Figure 4. A population of the caudally migrating cells are calbindin immunoreactive. DsRedEx/CAG was electroporated into the CGE of E13.5 telencephalic hemispheres, and horizontal sections were made after $40 \mathrm{~h}$ of culture. $\boldsymbol{A}, \boldsymbol{B}$, CGE-derived cells (red) moved toward the hippocampus in the caudal-most end of the telencephalon. $\boldsymbol{B}$, Higher magnification of the boxed area in $\boldsymbol{A}$. $\boldsymbol{C}-\boldsymbol{F}$, Horizontal sections were immunostained with anti-calbindin $(\boldsymbol{C}, \boldsymbol{E}, \boldsymbol{F}$; green). CGE-derived cells ( $\boldsymbol{C}, \boldsymbol{D}, \boldsymbol{F}$; purple) were classified as strongly positive ( $\boldsymbol{D}-\boldsymbol{F}$, arrowhead), weakly positive ( $\boldsymbol{D}-\boldsymbol{F}$, arrow), or negative populations for calbindin. Overall, $61.3 \pm 3.8 \%$ (SD) of the CGE-derived cells were calbindin positive. $\boldsymbol{D}-\boldsymbol{F}$, Higher magnification of the boxed area in C. Scale bars: $\boldsymbol{A}, 200 \mu \mathrm{m} ; \boldsymbol{B}, 50 \mu \mathrm{m} ; \boldsymbol{C}, 100 \mu \mathrm{m} ; \boldsymbol{D}-\boldsymbol{F}, 25 \mu \mathrm{m}$. Hip, Hippocampus.

hemisphere preparations obtained at E13.5 after $40 \mathrm{~h}$ in vitro, E15.5 mouse embryonic brains were used for this analysis. The horizontal sections of E15.5 mouse embryonic brains were immunostained with anti-calbindin (Fig. 5A-D). A significant number of calbindin-positive cells depicted a clear migratory stream from the CGE (Fig. 5C, arrows) to the hippocampus (Fig. $5 D$, arrows). Some calbindin-positive cells migrated rostrally in the stream (Fig. 5C, arrowhead). To investigate the birth date of the caudally migrating cells, we performed a birth-dating analysis using BrdU. Horizontal sections of brains, taken from E15.5 mice that had received a single pulse of BrdU on E12.5 (Fig. $5 E-H$ ) or E13.5 (Fig. $5 I-L$ ), were double immunostained with anticalbindin and anti-BrdU. Among all of the calbindin-positive caudally migrating cells, $35.7 \pm 1.8 \%$ (SD) $(n=629$ cells, three animals) were BrdU positive in animals that had received a BrdU injection on E12.5, whereas $25.0 \pm 3.2 \%(\mathrm{SD})(n=849$ cells, three animals) were BrdU positive in animals that had received a BrdU injection on E13.5, suggesting that at least some of the caudally migrating cells were early-born neurons, although the results do not exclude a later-born contribution from the CGE.

Homotopic transplantation of MGE cells to the MGE and heterotopic transplantation of CGE cells to the MGE

To clarify whether the different migration profiles of the CGE cells and the MGE cells were attributable to differences in their 


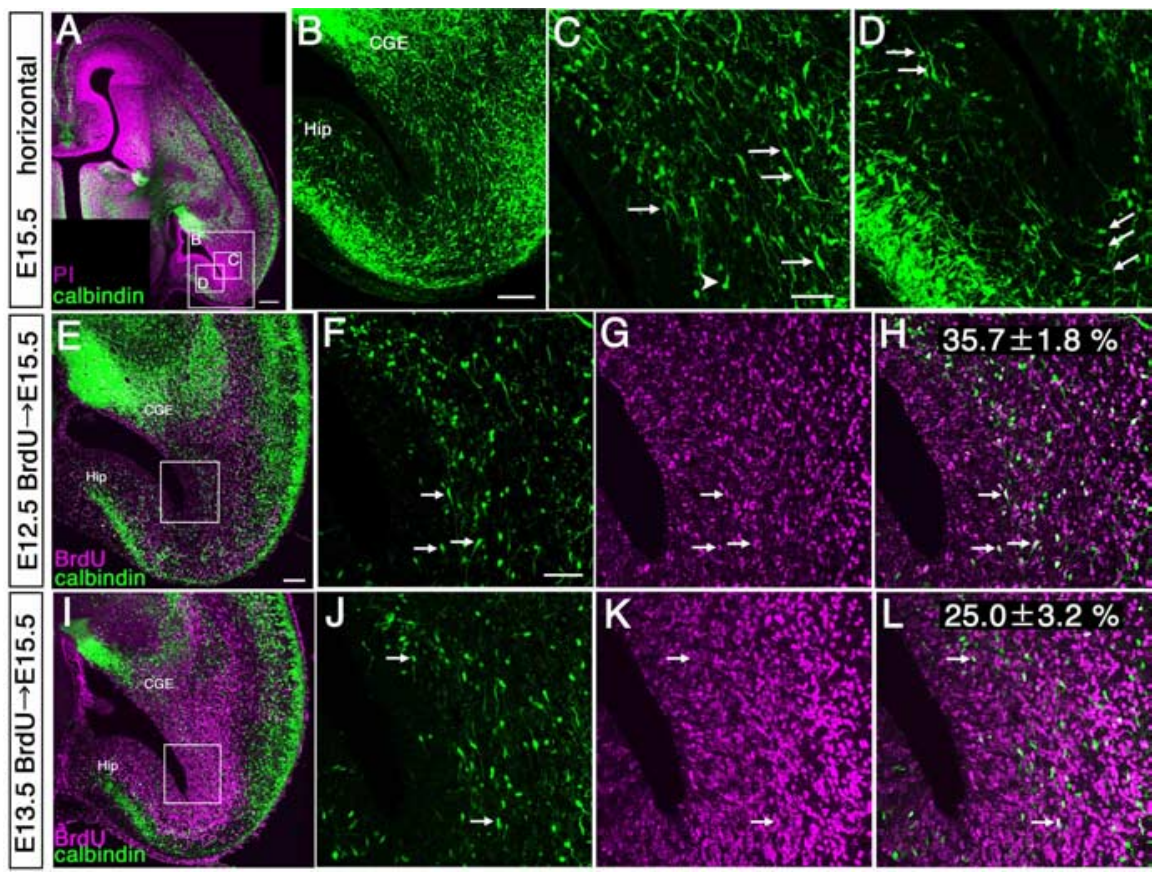

Figure 5. Existence of the CMS in vivo. $\boldsymbol{A}-\boldsymbol{D}$, Horizontal sections of $E 15.5$ mouse embryonic brains were immunostained with anti-calbindin (green), and their nuclei were counterstained with $\mathrm{PI}(\boldsymbol{A}$, purple). $\boldsymbol{B}-\boldsymbol{D}$, Higher magnification of the calbindin staining in the boxed areas in $\boldsymbol{A}$. $\boldsymbol{B}$, A significant number of calbindin-positive cells contributed to a clear migratory stream from the CGE to the hippocampus. C, Calbindin-positive cells moving caudally in the CGE (arrows). Some calbindin-positive cells migrated rostrally in the stream (arrowhead). D, Calbindin-positive cells moving toward the hippocampus (arrows). $\boldsymbol{E}-\boldsymbol{L}$, Birth-dating analysis of the caudally migrating cells. Horizontal sections of brains, taken from E15.5 mice that had received a single pulse of BrdU on E12.5 (E-H) or E13.5 (I-L), were double immunostained with anti-calbindin $(\boldsymbol{E}, \boldsymbol{F}, \boldsymbol{H}-\boldsymbol{J}$; green) and anti-BrdU $(\boldsymbol{E}, \boldsymbol{G}-\boldsymbol{I}, \boldsymbol{K}$, $\boldsymbol{L}$; purple). When BrdU was injected at E12.5, $35.7 \pm 1.8 \%$ (SD) of the calbindin-positive caudally migrating cells were BrdU positive $(\boldsymbol{F}-\boldsymbol{H}$, arrow), whereas $25.0 \pm 3.2 \%(S D)$ were BrdU positive ( $\boldsymbol{J}-\boldsymbol{L}$, arrow) in animals injected with BrdU on E13.5. $\boldsymbol{F}-\boldsymbol{H}$, Higher magnification of the boxed area in $\boldsymbol{E}$. $\boldsymbol{J}-\boldsymbol{L}$, Higher magnification of the boxed area in $\boldsymbol{I}$. Scale bars: $\boldsymbol{A}, 200 \mu \mathrm{m} ; \boldsymbol{B}, \boldsymbol{E}, \boldsymbol{I}, 100$ $\mu \mathrm{m} ; \boldsymbol{C}, \boldsymbol{D}, \boldsymbol{F}-\boldsymbol{H}, \boldsymbol{J}-\boldsymbol{L}, 50 \mu \mathrm{m}$. Hip, Hippocampus.

local environment or cell-intrinsic mechanisms, we performed transplantation experiments using telencephalic hemisphere cultures. First, we performed a homotopic transplantation of MGE cells to the MGE and a heterotopic transplantation of CGE cells to the MGE (Fig. 6A). Donor cells (MGE in the homotopic transplantation and CGE in the heterotopic transplantation) in the E13.5 hemisphere were locally electroporated with an FITClabeled oligonucleotide and the DsRedEx/CAG vector, and the transfected cells were dissected out as small fragments. These fragments were then transplanted into the MGE of another E13.5 hemisphere. FITC fluorescence was used to confirm the site of transfection in the donor hemispheres as well as the site of transplantation in the host hemispheres (Fig. $6 \mathrm{~B}$ ). For the quantitative analysis, the number of cells that had migrated out of the MGE after $40 \mathrm{~h}$ of culture was counted. When the electroporated E13.5 MGE cells were transplanted into the E13.5 MGE $(n=4)$, many MGE cells migrated out of the MGE and moved laterally toward the cerebral cortex (Fig. $6 C-F, K, L$ ). However, when the electroporated E13.5 CGE cells were transplanted into the E13.5 MGE $(n=4)$, a significantly smaller number of CGE cells migrated out of the MGE ( $p=0.00072$ ) (Fig. 6G-J,K,M). These results suggest that the local environment in the MGE was not sufficient to cause the CGE cells to migrate laterally, like MGE cells. As for the migration from the subpallium to the developing cerebral cortex, the CGE cells appear to have acquired different intrinsic mechanisms causing them to behave distinctly from MGE cells by this stage (E13.5) of development.
Homotopic transplantation of CGE cells to the CGE and heterotopic

transplantation of MGE cells to the CGE To investigate whether the local environment in the CGE is sufficient to cause cells to move like CGE-derived cells, we next performed the homotopic transplantation of CGE cells to the CGE and the heterotopic transplantation of MGE cells to the CGE using telencephalic hemisphere cultures (Fig. 7A). The donor CGE or MGE cells in the E13.5 hemisphere were labeled with an FITC-labeled oligonucleotide and the DsRedEx/CAG vector. The appropriate site of transplantation (CGE) in the host E13.5 hemispheres was confirmed using FITC fluorescence (Fig. 7B). For the quantitative analysis, the distribution of the transplanted cells was subdivided into four sectors: rostral (R), lateral (L), caudal (C), and medial (M). After 40 h of culture, the number of transplanted cells in $\mathrm{C}$ or $\mathrm{R}+\mathrm{L}$ was counted. When electroporated E13.5 CGE cells were transplanted into the E13.5 CGE ( $n=4$; total, 570 cells), most of the CGE cells migrated caudally (Fig. 7C$E, I, M)$. When electroporated E13.5 MGE cells were transplanted into the E13.5 CGE ( $n=4$; total, 673 cells), the MGE cells migrated laterally and rostrally (Fig. $7 F-H, J, N)$. In sector $\mathrm{C}$, the percentage of transplanted MGE cells was significantly smaller than that of transplanted CGE cells $(p=0.0015)$. In sector $\mathrm{R}+\mathrm{L}$, the percentage of transplanted MGE cells was significantly larger than that of transplanted CGE cells ( $p=0.0019)$. These results suggest that the local environment in the CGE is not sufficient to cause the MGE cells to behave as CGE-derived cells and that the migratory mechanisms of MGE cells and CGE cells are intrinsically determined as early as E13.5. Thus, the combination of the CGE local environment and the cell-intrinsic machinery in CGE-derived cells is important for the caudally directed migration of these cells.

\section{Discussion}

Although the caudal migration of CGE-derived cells was originally suggested by Nery et al. (2002) in fixed brains of Dlx2-tauLacZ knock-in mice, the migratory behavior of these cells has not been directly analyzed in detail. Here, we have provided direct evidence that CGE-derived cells do migrate caudally and have further characterized this pathway in the developing mouse forebrain. While MGE cells migrated laterally and spread widely throughout the cerebral cortex, CGE cells migrated caudally toward the caudal-most end of the telencephalon. Because this migration path differs from the well known streams of MGE/LGEderived interneurons, we named this novel migratory stream the CMS.

Focal electroporation into the telencephalic hemisphere and entire telencephalic hemisphere cultures

To analyze the tangential migration of GABAergic interneurons from the subpallium to the pallium, we developed a new technique combining focal electroporation into the telencephalic 
hemisphere and entire telencephalic hemisphere cultures to visualize the migration of interneurons from specific parts of the hemispheres. In the entire telencephalic hemisphere cultures, the present work (Fig. $1 F-P$ ) (supplemental Fig. 2 and supplemental movie 1, available at www. jneurosci.org as supplemental material) and the other works (Nagata and Terashima, 1994; Honda, Tabata, and Nakajima, unpublished observations) showed that the neuronal migration occurred at least with similar physiological integrity to that in the slice cultures reported previously (de Carlos et al., 1996; Anderson et al., 1997b; Tamamaki et al., 1997; Lavdas et al., 1999; Wichterle et al., 1999; Polleux et al., 2002; Tanaka et al., 2003). Our new technique has several advantages over previous experimental approaches. The main advantage of focal electroporation over DiI (1,1' -dioctadecyl-3,3,3',3' -tetramethylindocarbocyanine perchlorate) labeling is that the new technique allows us to perform overexpression or loss-offunction experiments using any molecule related to interneuron migration. Moreover, particular structures of the developing brain can be specifically labeled using focal electroporation. The main advantage of telencephalic hemisphere cultures over slice-culture experiments is that the new technique allows us to analyze the neuronal migration in three dimensions. In the present study, if we had performed the experiments using ordinary coronal slices of the brain, we would have been unable to observe the CMS. A new approach to in utero imaging of the $\mathrm{MZ}$ in living mouse embryos was recently reported by Ang et al. (2003). Their in utero imaging approach has an advantage over entire telencephalic hemisphere cultures in that the physiological integrity of interneuron migration is preserved. However, precise manipulation, such as specific cell labeling or gene transfection into a small, defined portion of the GE, would be more easily and accurately accomplished using the new technique reported in this study.

\section{Characteristics of CGE-derived cells}

Recently, attempts have been made to characterize the neuronal subtypes that arise in each part of the GE (Nery et al., 2002, 2003; Ang et al., 2003; Tamamaki et al., 2003; Lopez-Bendito et al., 2004; Xu et al., 2004). Xu et al. (2004) reported that parvalbuminand somatostatin-expressing interneurons originated primarily within the MGE, whereas calretinin-expressing interneurons derived mainly from the CGE. Lopez-Bendito et al. (2004) demonstrated that many of the GAD65-green fluorescent protein (GFP) cells, which were born mostly at late stages and preferentially in the CGE, expressed calretinin. Unfortunately, we could not observe calretinin-expressing CGE cells in the present study, most likely because of the limited culture time for the entire telencephalic hemisphere cultures (discussed above). In the present study, in vitro and in vivo immunohistochemical analyses revealed that a population of the caudally migrating cells were calbindin immunoreactive (Figs. 4, 5). In the caudal-most cortices, $61.3 \%$ of the CGE-derived cells were either strongly positive or weakly positive for calbindin (Fig. $4 C-F$ ). Lopez-Bendito et al. (2004) reported that only 4\% of the GAD65-GFP cells were calbindin immunoreactive in the embryonic stage. This difference in calbindin immunoreactivity may be attributable to the distinct population of the cells examined. Although GAD65-GFP cells are mainly generated in the CGE during the late stages of embryonic development, these cells also arise throughout embryonic development and from all three GEs. In the present study, we specifically labeled the CGE cells in the early stage of embryonic development (E13.5). Ang et al. (2003) suggested that the migrating interneurons in the MZ emerging from the CGE were calbindin immunoreactive. Furthermore, Nery et al. (2002, 2003) suggested that tangentially migrating interneurons, including CGE cells, became calbindin immunoreactive once they differentiated.

\section{Role of the CMS in the developing mouse forebrain}

In the present study, the transplantation experiments suggested that the direction of migration from the subpallium to the developing cerebral cortex was already determined in CGE and MGE 

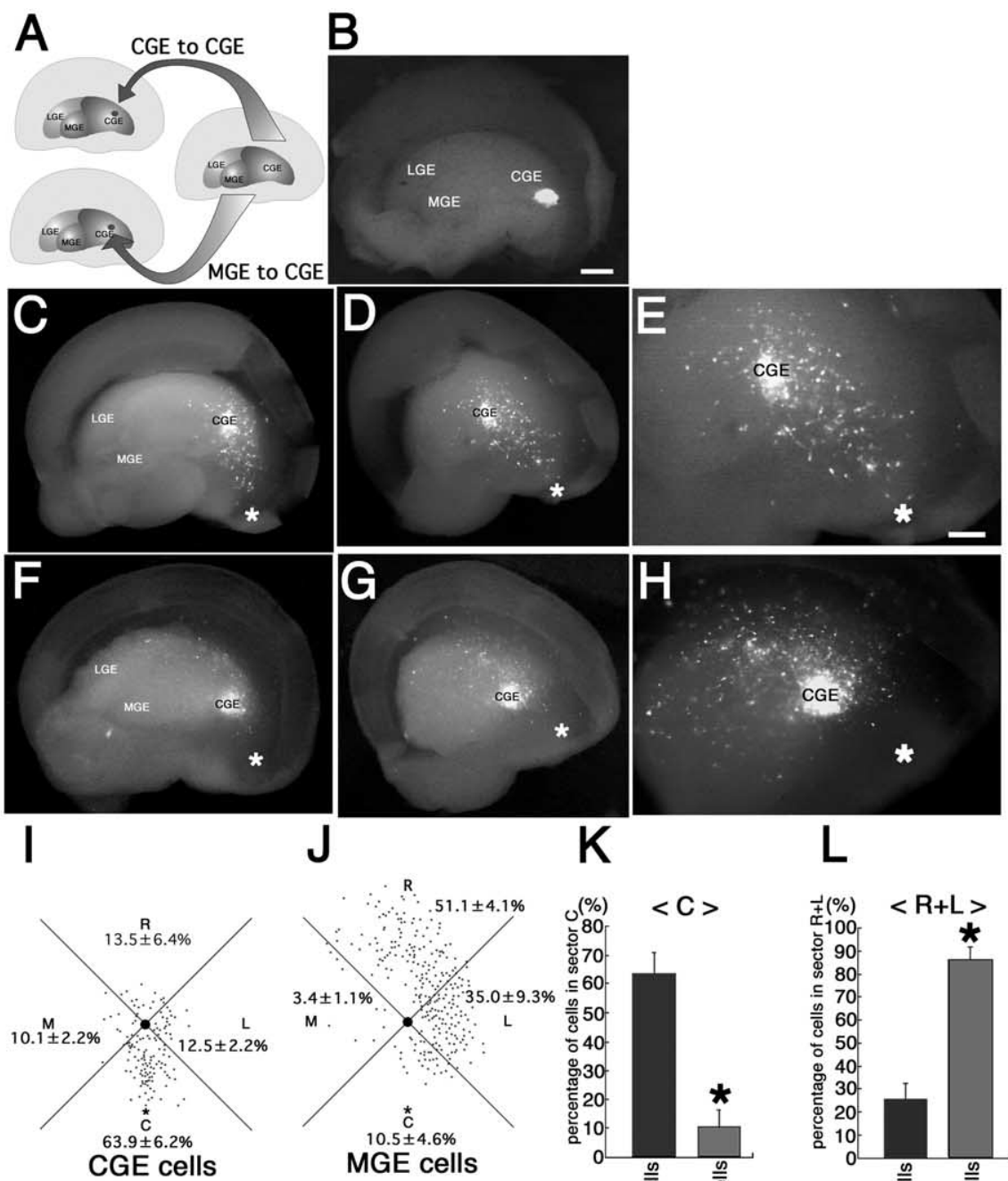

\section{$\mathrm{K}$}

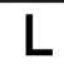

R.
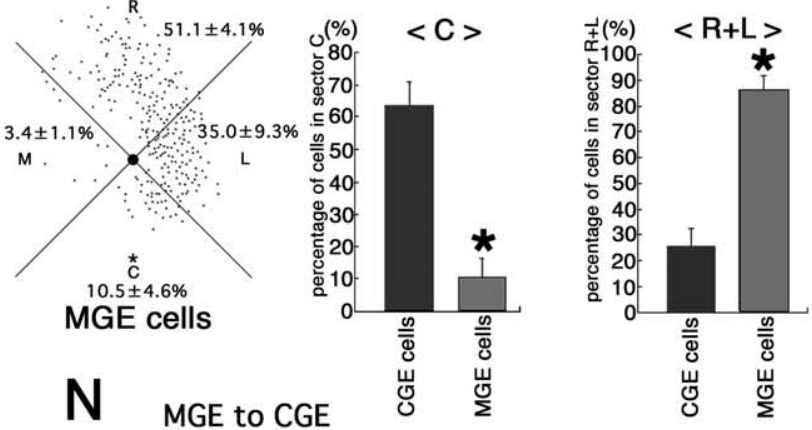

M

\section{CGE to CGE}
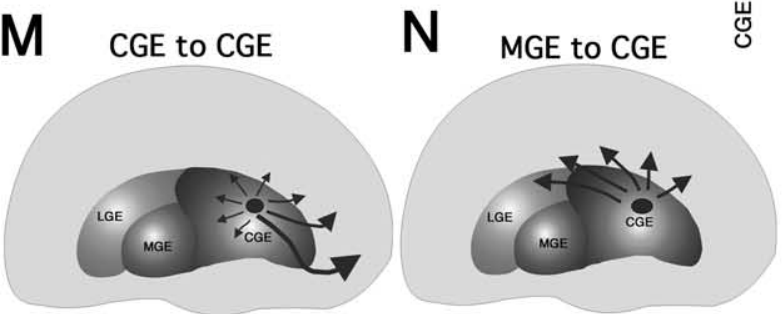

Figure 7. Homotopic transplantation of CGE cells to the CGE and heterotopic transplantation of MGE cells to the CGE. $A$, Schema of the homotopic and heterotopic transplantations to the CGE in telencephalic hemisphere cultures. $\boldsymbol{B}$, Transplantation to the CGE. Small fragments dissected from the locally electroporated CGE and labeled with FITC oligonucleotides were transplanted into the CGE of other E13.5 hemispheres. $\boldsymbol{C}-\boldsymbol{H}$, Small fragments of the CGE $(\boldsymbol{C}-\boldsymbol{E})$ or MGE $(\boldsymbol{F}-\boldsymbol{H})$ taken from the locally electroporated E13.5 hemisphere and labeled with DsRedEx/CAG were transplanted into the CGE of other E13.5 hemispheres, and the hemispheres were cultured for 40 h. $\mathbf{C}-\boldsymbol{E}$, When the electroporated CGE cells were transplanted into the CGE, most of the transplanted cells migrated caudally. $\boldsymbol{F}-\boldsymbol{H}$, When the electroporated MGE cells were transplanted to the CGE, however, the transplanted cells migrated laterally and rostrally. $\boldsymbol{C}, \boldsymbol{F}$, Medial view of the cultured telencephalic hemisphere. $\boldsymbol{D}, \boldsymbol{E}, \boldsymbol{G}, \boldsymbol{H}$, Caudally shifted medial view of the hemisphere in $\boldsymbol{C}$ and $\boldsymbol{F}$, respectively. $\boldsymbol{E}, \boldsymbol{H}$, Higher magnifications of $\boldsymbol{D}$ and $\boldsymbol{G}$, respectively. $\boldsymbol{C}-\boldsymbol{H}$, The asterisks indicate the caudal end of the CGE. $\boldsymbol{I}, \boldsymbol{J}$, Distribution of the transplanted CGE $(\boldsymbol{I})$ and MGE $(\boldsymbol{J})$ cells in the GE after $40 \mathrm{~h}$ in vitro. Each dot represents one cell. The number of migrating cells in each of the four sectors [rostral (R), caudal (C), medial (M), and lateral (L)] was counted [average \pm SD (\%); data from 4 independent experiments]. The black dot in the center represents the site of the transplantation, and the asterisk in sector C represents the caudal end of the CGE. $\boldsymbol{K}, \boldsymbol{L}$, Quantification of the percentages of transplanted cells in sector $C(\boldsymbol{K})$ and sector $R+L(\boldsymbol{L})$. In sector $C$, the percentage of transplanted MGE cells was significantly smaller than the percentage of transplanted CGE cells ( ${ }^{*} p<0.002$; data from 4 independent experiments). In sector $R+L$, the percentage of transplanted MGE cells was significantly larger than the percentage of transplanted CGE cells $\left({ }^{*} p<0.002\right.$; data from 4 independent experiments). $\boldsymbol{M}$, Schema of the homotopic transplantation of (GE cells into the CGE. $\boldsymbol{N}$, Schema of the heterotopic transplantation of MGE cells into the CGE. Scale bars: $\boldsymbol{B}-\boldsymbol{D}, \boldsymbol{F}, \boldsymbol{G}, 400 \mu \mathrm{m} ; \boldsymbol{E}, \boldsymbol{H}, 200 \mu \mathrm{m}$. cells by at least E13.5 through a combination of the local environment and cellintrinsic mechanisms in the migrating GE cells. This conclusion is consistent with the results by Nery et al. (2002), who reported the early commitment of MGE and CGE cell migration by E13.5. They performed in utero transplantation and observed that at postnatal day 21, MGE cells that had been heterotopically transplanted to the CGE at E13.5 migrated to the cortex in a pattern similar to that of MGE homotopic transplants, suggesting that the MGE and CGE cells had intrinsically different migratory properties that had been specified by E13.5.

When the distribution of the CGEderived cells in the cultured telencephalic hemispheres was analyzed at $40 \mathrm{~h}$ after focal electroporation into E13.5 CGE (Fig. $2 D-F, I)$, the majority of the CGE-derived cells migrated caudally toward the caudalmost end of the telencephalon. Some CGE-derived cells, however, also migrated laterally or rostrally (Fig. 2I). Because we observed that the MGE cells migrated laterally through the LGE and CGE to the cerebral cortex (Fig. 1D,E), MGE cells passing through the CGE would also have been labeled by the electroporation into the CGE. Thus, the laterally and rostrally migrated cells observed after focal electroporation into the CGE may have included MGE-derived cells that had passed through the CGE region during electroporation.

Time-lapse imaging of slice cultures and an in vivo immunohistochemical study revealed a clear migratory stream of a population of CGE-derived cells from the CGE to the hippocampus (Figs. 3-5). We also observed that some of the CGEderived cells in the migratory stream changed their direction toward the MZ before entering the hippocampus or within the hippocampus, whereas others reached the $\mathrm{MZ}$ of the posterior cerebral cortex (Fig. 3B-D) (supplemental Fig. 3, available at www.jneurosci.org as supplemental material). These observations are consistent with results showing that CGE cells contribute to many mature structures in the adult brain, including the hippocampus and posterior cerebral cortex, as shown in the in vivo fate-mapping experiment (Nery et al., 2002). The transcription factor Dlx2, which is required together with Dlx1 for the differentiation of interneurons (Anderson et al., 1997a,b; Marin et al., 2000), is expressed in the subpallial telencephalon, including the MGE, LGE, and CGE (Nery et al., 2002). Previous analyses in mice carrying a mutation in both $D l x 1$ 
and $D l \times 2(\mathrm{Dlx}-1 / 2)$ revealed that the number of GABAergic interneurons in the cerebral cortex and hippocampus was lower than normal: $\sim 25$ and $0 \%$ of GABAergic interneurons remained in these structures, respectively (Anderson et al., 1997b; Pleasure et al., 2000). An analysis in mice lacking the Nkx2.1 homeobox gene, in which the MGE is respecified to produce LGE cells, revealed that the number of GABAergic interneurons was also lower than normal in the cerebral cortex and hippocampus but that these reductions were more moderate than those in Dlx-1/2 mice: $\sim 50$ and $30-40 \%$ of GABAergic interneurons remained in these structures, respectively (Sussel et al., 1999; Pleasure et al., 2000). The in vivo fate-mapping experiment of E13.5 LGE cells showed that E13.5 LGE cells contributed to neither the adult cerebral cortex nor the hippocampus (Nery et al., 2002). Although several reports have shown that the late developmental stage of the LGE or other structures outside the GEs supply GABAergic interneurons to the cerebral cortex or hippocampus (Anderson et al., 1997a, 2001; Marin et al., 2000), the present study suggests that at least a population of CGE cells migrating along the CMS may supply interneurons to the hippocampus and posterior cerebral cortex. Further analysis of the molecular mechanisms regulating the CMS will be essential to understanding the development of the brain.

\section{References}

Alifragis P, Liapi A, Parnavelas JG (2004) Lhx6 regulates the migration of cortical interneurons from the ventral telencephalon but does not specify their GABA phenotype. J Neurosci 24:5643-5648.

Anderson SA, Qiu M, Bulfone A, Eisenstat DD, Meneses J, Pedersen R, Rubenstein JL (1997a) Mutations of the homeobox genes Dlx-1 and Dlx-2 disrupt the striatal subventricular zone and differentiation of late born striatal neurons. Neuron 19:27-37.

Anderson SA, Eisenstat DD, Shi L, Rubenstein JL (1997b) Interneuron migration from basal forebrain to neocortex: dependence on Dlx genes. Science 278:474-476.

Anderson SA, Marin O, Horn C, Jennings K, Rubenstein JL (2001) Distinct cortical migrations from the medial and lateral ganglionic eminences. Development 128:353-363.

Ang Jr ES, Haydar TF, Gluncic V, Rakic P (2003) Four-dimensional migratory coordinates of GABAergic interneurons in the developing mouse cortex. J Neurosci 23:5805-5815.

Avishai-Eliner S, Yi SJ, Baram TZ (1996) Developmental profile of messenger RNA for the corticotropin-releasing hormone receptor in the rat limbic system. Brain Res Dev Brain Res 91:159-163.

Casarosa S, Fode C, Guillemot F (1999) Mash1 regulates neurogenesis in the ventral telencephalon. Development 126:525-534.

Corbin JG, Gaiano N, Machold RP, Langston A, Fishell G (2000) The Gsh2 homeodomain gene controls multiple aspects of telencephalic development. Development 127:5007-5020.

Corbin JG, Nery S, Fishell G (2001) Telencephalic cells take a tangent: non-radial migration in the mammalian forebrain. Nat Neurosci [Suppl] 4:1177-1182.

de Carlos JA, Lopez-Mascaraque L, Valverde F (1996) Dynamics of cell migration from the lateral ganglionic eminence in the rat. J Neurosci 16:6146-6156.

de Lecea L, del Rio JA, Soriano E (1995) Developmental expression of parvalbumin mRNA in the cerebral cortex and hippocampus of the rat. Brain Res Mol Brain Res 32:1-13.

de Lecea L, del Rio JA, Criado JR, Alcantara S, Morales M, Danielson PE, Henriksen SJ, Soriano E, Sutcliffe JG (1997) Cortistatin is expressed in a distinct subset of cortical interneurons. J Neurosci 17:5868-5880.

Denaxa M, Chan CH, Schachner M, Parnavelas JG, Karagogeos D (2001) The adhesion molecule TAG-1 mediates the migration of cortical interneurons from the ganglionic eminence along the corticofugal fiber system. Development 128:4635-4644.

Flames N, Long JE, Garratt AN, Fischer TM, Gassmann M, Birchmeier C, Lai C, Rubenstein JL, Marin O (2004) Short- and long-range attraction of cortical GABAergic interneurons by neuregulin-1. Neuron 44:251-261.
Freund TF, Buzsaki G (1996) Interneurons of the hippocampus. Hippocampus 6:347-470.

Gall C, Brecha N, Chang KJ, Karten HJ (1984) Ontogeny of enkephalin-like immunoreactivity in the rat hippocampus. Neuroscience 11:359-379.

Hill JM, Agoston DV, Gressens P, McCune SK (1994) Distribution of VIP mRNA and two distinct VIP binding sites in the developing rat brain: relation to ontogenic events. J Comp Neurol 342:186-205.

Lavdas AA, Grigoriou M, Pachnis V, Parnavelas JG (1999) The medial ganglionic eminence gives rise to a population of early neurons in the developing cerebral cortex. J Neurosci 19:7881-7888.

Lopez-Bendito G, Sturgess K, Erdelyi F, Szabo G, Molnar Z, Paulsen O (2004) Preferential origin and layer destination of GAD65-GFP cortical interneurons. Cereb Cortex 14:1122-1133.

Marin O, Rubenstein JL (2001) A long, remarkable journey: tangential migration in the telencephalon. Nat Rev Neurosci 2:780-790.

Marin O, Rubenstein JL (2003) Cell migration in the forebrain. Annu Rev Neurosci 26:441-483.

Marin O, Anderson SA, Rubenstein JL (2000) Origin and molecular specification of striatal interneurons. J Neurosci 20:6063-6076.

Marin O, Yaron A, Bagri A, Tessier-Lavigne M, Rubenstein JL (2001) Sorting of striatal and cortical interneurons regulated by semaphorinneuropilin interactions. Science 293:872-875.

Nadarajah B, Parnavelas JG (2002) Modes of neuronal migration in the developing cerebral cortex. Nat Rev Neurosci 3:423-432.

Nadarajah B, Alifragis P, Wong RO, Parnavelas JG (2002) Ventricledirected migration in the developing cerebral cortex. Nat Neurosci $5: 218-224$.

Nadarajah B, Alifragis P, Wong RO, Parnavelas JG (2003) Neuronal migration in the developing cerebral cortex: observations based on real-time imaging. Cereb Cortex 13:607-611.

Nagata I, Terashima T (1994) Migration behavior of granule cells on laminin in cerebellar microexplant cultures from early postnatal reeler mutant mice. Int J Dev Neurosci 12:387-395.

Nery S, Fishell G, Corbin JG (2002) The caudal ganglionic eminence is a source of distinct cortical and subcortical cell populations. Nat Neurosci 5:1279-1287.

Nery S, Corbin JG, Fishell G (2003) Dlx2 progenitor migration in wild type and Nkx2.1 mutant telencephalon. Cereb Cortex 13:895-903.

Niwa H, Yamamura K, Miyazaki J (1991) Efficient selection for highexpression transfectants with a novel eukaryotic vector. Gene 108:193199.

Parnavelas JG (2000) The origin and migration of cortical neurones: new vistas. Trends Neurosci 23:126-131.

Pleasure SJ, Anderson S, Hevner R, Bagri A, Marin O, Lowenstein DH, Rubenstein JL (2000) Cell migration from the ganglionic eminences is required for the development of hippocampal GABAergic interneurons. Neuron 28:727-740.

Polleux F, Whitford KL, Dijkhuizen PA, Vitalis T, Ghosh A (2002) Control of cortical interneuron migration by neurotrophins and PI3-kinase signaling. Development 129:3147-3160.

Powell EM, Mars WM, Levitt P (2001) Hepatocyte growth factor/scatter factor is a motogen for interneurons migrating from the ventral to dorsal telencephalon. Neuron 30:79-89.

Puelles L, Kuwana E, Puelles E, Bulfone A, Shimamura K, Keleher J, Smiga S, Rubenstein JL (2000) Pallial and subpallial derivatives in the embryonic chick and mouse telencephalon, traced by the expression of the genes Dlx-2, Emx-1, Nkx-2.1, Pax-6, and Tbr-1. J Comp Neurol 424:409-438.

Sussel L, Marin O, Kimura S, Rubenstein JL (1999) Loss of Nkx2.1 homeobox gene function results in a ventral to dorsal molecular respecification within the basal telencephalon: evidence for a transformation of the pallidum into the striatum. Development 126:3359-3370.

Tabata H, Nakajima K (2001) Efficient in utero gene transfer system to the developing mouse brain using electroporation: visualization of neuronal migration in the developing cortex. Neuroscience 103:865-872.

Tabata H, Nakajima K (2003) Multipolar migration: the third mode of radial neuronal migration in the developing cerebral cortex. J Neurosci 23:9996-10001.

Takeda K, Koshimoto H, Uchiumi F, Haun RS, Dixon JE, Kato T (1989) Postnatal development of cholecystokinin-like immunoreactivity and its mRNA level in rat brain regions. J Neurochem 53:772-778.

Tamamaki N, Fujimori KE, Takauji R (1997) Origin and route of tangen- 
tially migrating neurons in the developing neocortical intermediate zone. J Neurosci 17:8313-8323.

Tamamaki N, Yanagawa Y, Tomioka R, Miyazaki J, Obata K, Kaneko T (2003) Green fluorescent protein expression and colocalization with calretinin, parvalbumin, and somatostatin in the GAD67-GFP knock-in mouse. J Comp Neurol 467:60-79.

Tanaka D, Nakaya Y, Yanagawa Y, Obata K, Murakami F (2003) Multimodal tangential migration of neocortical GABAergic neurons independent of GPI-anchored proteins. Development 130:5803-5813.

Wichterle H, Garcia-Verdugo JM, Herrera DG, Alvarez-Buylla A (1999) Young neurons from medial ganglionic eminence disperse in adult and embryonic brain. Nat Neurosci 2:461-466.

Wichterle H, Turnbull DH, Nery S, Fishell G, Alvarez-Buylla A (2001) In utero fate mapping reveals distinct migratory pathways and fates of neurons born in the mammalian basal forebrain. Development 128:37593771.

Wichterle H, Alvarez-Dolado M, Erskine L, Alvarez-Buylla A (2003) Permissive corridor and diffusible gradients direct medial ganglionic eminence cell migration to the neocortex. Proc Natl Acad Sci USA 100:727-732.

Xu Q, Cobos I, De La Cruz E, Rubenstein JL, Anderson SA (2004) Origins of cortical interneuron subtypes. J Neurosci 24:2612-2622.

Yozu M, Tabata H, Nakajima K (2004) Birth-date dependent alignment of GABAergic neurons occurs in a different pattern from that of nonGABAergic neurons in the developing mouse visual cortex. Neurosci Res 49:395-403. 